\title{
Billion Cells per Liter
}

National Cancer Institute

\section{Source}

National Cancer Institute. Billion Cells per Liter. NCI Thesaurus. Code C67249.

A unit of cell concentration expressed as a number of cells in billions per unit volume equal to one liter. 